\title{
首都高速道路 計 画と照明
}

資料

専門会員 日 高 澄*

\section{1.はしがき}

近年自動車の増加がはなはだしく, 東京都内の自動車 交通緩和対策の 1 つとして, 昭和 34 年 6 月 17 日に首都 高速道路公団が設立され, 都内高速道路の建設が開始さ れた.

この高速道路は 8 路線延長約 $70 \mathrm{~km}$ の規模で, 一般街 路とは立体交差によって分離された自動車専用の道路で あり，償却期間中は公団が管理する有料道路であるが， それが完了すれば都道として公開される予定のものであ る.

高速道路の建設は昭和 34 年度より開始され, 1 号線打 よび 4 号線を 現在着工中であるが，昭和 40 年度までに 全路線の完成が望まれている.

現在のところ最も早く開通する区間としては，1号線 京橋〜芝海岸通り 3 丁目約 $4.8 \mathrm{~km}$ 扰よび京橋〜本町間 約 $1.7 \mathrm{~km}$ が，それぞれ昭和 37 年 12 月打よび昭和 38 年 4 月に供用開始予定されている.

近年道路照明の必要性が強調され, 首都高速道路公団 でも, 夜間交通の安全性と快適性をうるための不可欠の ものとして, 道路照明施設を設けるととになった

ここでは, 道路照明に最も関連のある高速道路の概要 扎よび照明施設計画の状況について述べる.

为 1 图

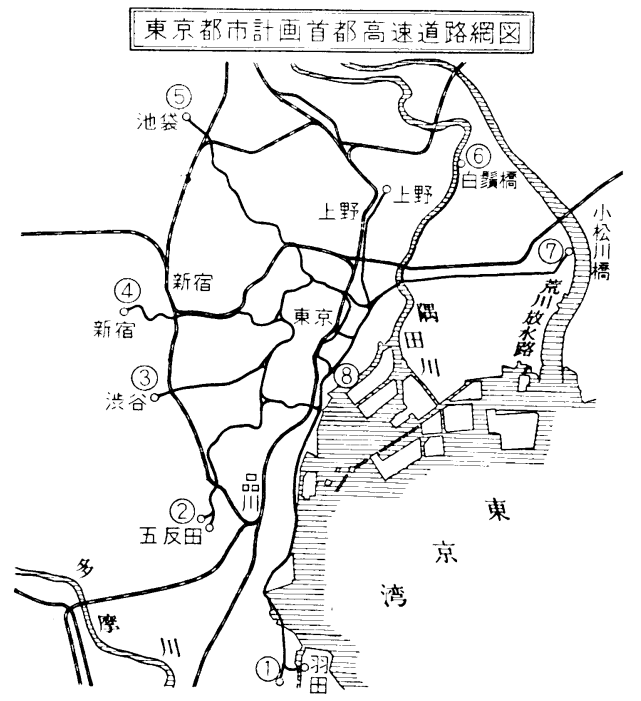

\section{2. 首都高速道路の概要}

\section{1 路線および一般形状}

首都高速道路の路線は, 都心部と東京都環状 6 号線と を結ぶ放射線で，路線経過地の選定は交通調查を基礎に して，できるだけ民有地をさけて，公有地，河川敷また は既設の広幅員の道路を通過するよう計画されたもので ある(为1図)。

この高速道路は外国のハイウエイまたは日本道路公団 の道路のような, 都市間の通過交通を主要目的とするも のではなく, 都市内の交通混雑な緩和するためのもの で, 自動車の速度よりも通過台数が特に多いのが特長で ある。

したがって，一般平面街路 とは約 90 筒所の出口また は入口で連絡されて，一般街路からの流出入に便利なよ うに計画されている。

高速道路の一般形状としては次の種類に大別される.

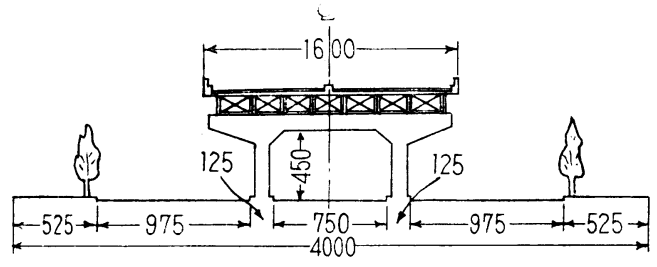

为 2 図広幅員の道路に設けた高架式道路

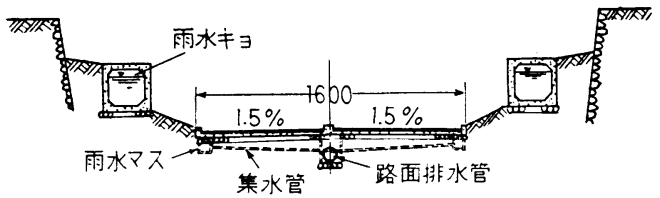

为3図河底 (掘割) 部に設けた道路

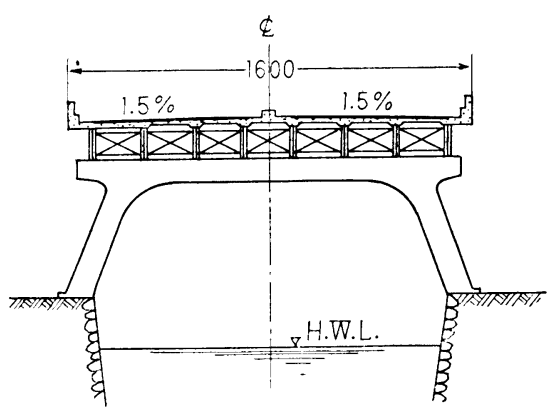

为4図河川上に設けた高架式道路 

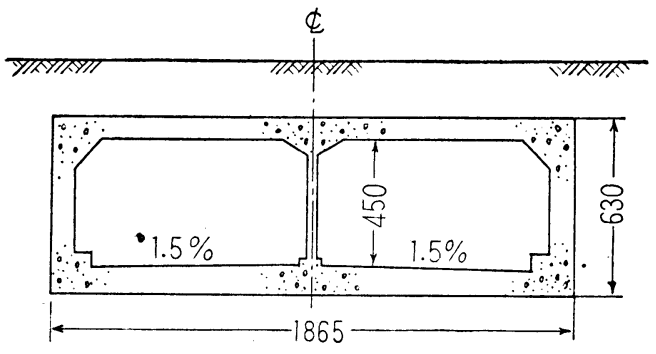

为5図トンネル

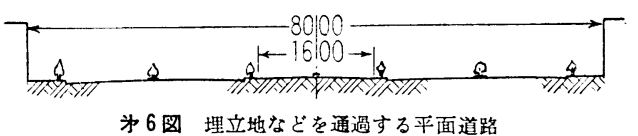

（1）広幅員の道路の中央に設けた高架式道路（为 2 図)

（2）河低 (掘割) 部に設けた道路（为 3 図）

（3）河川上に設けた高架式道路（为4 图）

(4) トンネル（为 5 図）

（5）埋立地などを通過する平面道路（为 6 図）

\section{2 高速道路の標準断面および構造}

首都高速道路の標準断面は为 7 図のように，車線のほ が中央分離帯, 路肩扎よび高欄部分を有するものであ り，その仕様で照明に関係を有する点を要約すれば，次 のと打りである.

$\varepsilon$

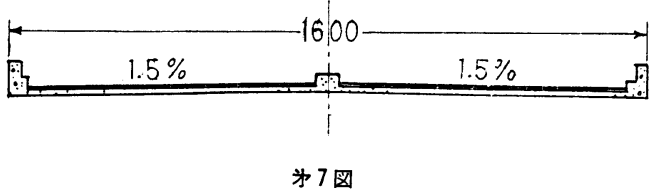

\subsection{1 設計速度}

毎時 $60 \mathrm{~km}$ ，ただし地形その他やむを得ない事情によ り, これにより難い区間は毎時 $50 \mathrm{~km}$ または $40 \mathrm{~km}$.

\subsection{2 幅員構成}
（1）分離 4 車線
(一方向 2 車線)
(2) 総幅員 $16 \mathrm{~m}$ 以上
(3) 車線幅員
$3.25 \mathrm{~m}$
(4) 路 肩
$0.50 \mathrm{~m}$ 以上
（5）中央分離帯 $1.00 \mathrm{~m}$ 以上

\subsection{3 最小曲率半径}

\begin{tabular}{c|c}
\hline 設計 速 度 $[\mathrm{km} / \mathrm{h}]$ & 曲率 半 经 $[\mathrm{m}]$ \\
\hline 60 & 110 \\
50 & 80 \\
40 & 50 \\
\hline
\end{tabular}

\subsection{4 視 距}

車線の中心線上 $1.5 \mathrm{~m}$ の高さから, 中心線上にある高 さ $0.15 \mathrm{~m}$ の物つ頂点を見通すことができる距離を, 車

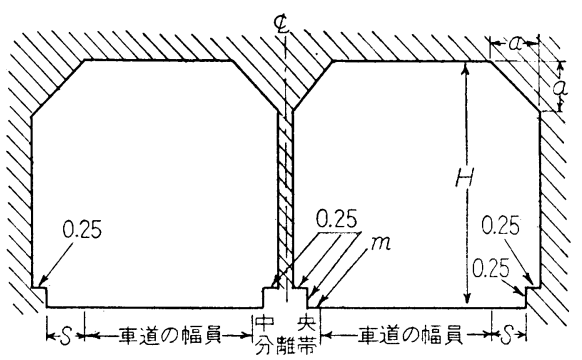

（a）中央分敨带のある場合

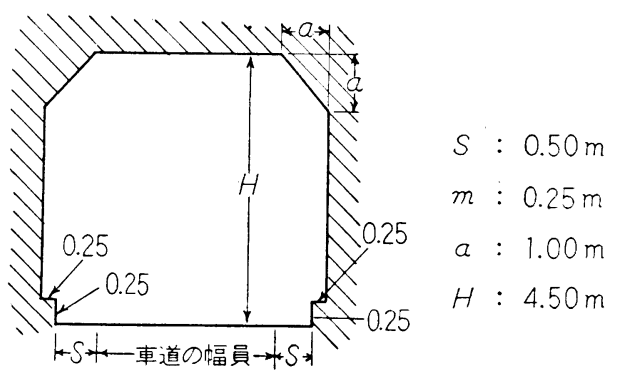

（b）中央分離带のない場合 为 8 図高速道路の建築限界

道の中心線に沿って計った長さを視距といい, 各設計速 度 $60,50,40 \mathrm{~km}$ に対してその長さは $75,65,50 \mathrm{~m}$ 以 上とする.

\section{2 .5 建築限界}

自動車を安全に通過させるために, 道路（トンネルな 含めて) の上部打よび側方部分に, 各種障害物（灯器な ど施設物を含を）を設けてはならない部分を定めてい る(为 8 図).

照明関係の場合もこの建築限界に制約されるととが多 いので, 特にトンネルなどの場合は, あらかじめての建 築限界外に照明器具, 配線などを設けられるような構造 にして抢かなければならない。

また灯柱の場合でも中央分離帯が $1 \mathrm{~m}$ の場合は, 建築 限界一杯なので中央式には設置できない.

\section{3. 高速道路の照明計画}

前述のように道路の用地面が限られているため, 自動 車の速度扣よび通過台数が大きいのに対し, 道路の線 形，構造ははなはだ窮屈な状態である.

照明によって夜間交通の速度と交通量を増加し, 運転 の安全と快適さを確保することは, 道路の経済打よび運 用上からも必要である.

首都高速道路公団では技術委員会照明部会を設けて, 照明学会をはじめ各方面の方々の意見をうかがって, 道 路照明関係の基準となる事項を作成しつつあるので，そ の要点を明する.

\section{1 高架, 河底部および平面道路}

\section{1 .1 基準照度}


道路照明の基準となる要素としては，照度のほかにい くつかの事項があるわけであるが，簡明のために照度の みについて記した。

照度については「夜間前照明灯を下向き点灯して, 設 計速度 $60 \mathrm{~km} / \mathrm{h}$ で安全に所要台数 (1 車線, 1 時間当り 約 1,500 台）を走行させうる明るさ」を目標とし, JIS, 照度基準，日本道路公団で行なわれた「道路照明試験研 究」拓よび諸外国の例を勘案して，次の值をとる.

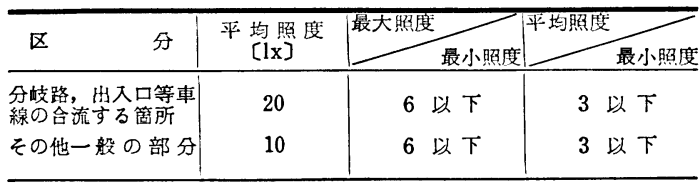

車線の合流すの筒所の照度を $201 \mathrm{x}$ としたのは，ての 箇所は衝突その他の事故が起りやすいためである.

\section{1 .2 光源および照明方式}

一般の高架部分では水銀灯の柱上方式とし，河底部， 分岐路出入口など，特殊な個所はけい光灯または水銀灯 をその状沉に応じた方法で設置する。

柱上の場合の設置高さは, けい光灯で $6 \mathrm{~m}$ 以上, 400 $\mathrm{W}$ 水銀灯で $8 \mathrm{~m}$ 以上, $700 \mathrm{~W}$ 水銀灯 $10 \mathrm{~m}$ で以上とする

\section{1.3 配}

高架道路では，一般に道路の両側高闌上に設置する. 中央分離帯の十分広くとってある区域は，分離帯上に設 置する.

両側に設ける場合は，千魚配列と対向配列があるが， これは路面の配光外観拓よび保守を勘案して決定する.

\section{2 トンネ}

現在トンネル構造になる個所としては，八重州トンネ ル(延長約 $1,500 \mathrm{~m}$ ) を初めとして 10 個所内外, 延長約 $4.5 \mathrm{~km}$ が計画されている.

\subsection{1 照 度}

トンネル内部の照度は, 諸外国の例拓よび名神トンネ ル照明実験研究（日本道路公団一照明学会）の報告を勘 案して $50 \mathrm{~lx}$ 以上とする. 夜間は減光する.

トンネルの入車線側入口部分は, 運転者の目の生理学 的順応に応ずる緩和照明を行なう，緩和照明地帯の人工 照明による照度は, 個々のトンネルで方位打よび入口遮 光帯の状況が相違しているので, 拒の报のの場合につい て天空照明計算，または実験等で找の打の決定する．出 車側は, 目の順応が速いので緩和照明は行なわない.

\subsection{2 光源および照明方式}

光源はけい光灯とし, 一般にトンネル両側部分に器具 を取付ける，入口緩和照明の方法は增灯部を設け，入口
遮光帯, 方位などを考虑し, 蒲山曲線に準じた照度漸減 方式をとり，その段階は通常 $3 \sim 4$ 段階程度とし光電管 または光電池によって制御する.

トンネル内部の緩和照明を行なわない一般の部分は, 器具を連続列とする.

\section{4. その他の照明}

以上述べた高速道路照明の外に, 高架下部招よび標識 板の照明を行なうことが考慮されている.

\section{1 高架下部照明}

河川上部構造以外の高架道路の下部は, 一般街路ま たは駐車場として使用される部分が多い.

ての部分の照明として,けい光灯による平均照度約 5 $1 \mathrm{y}$ 程度が考虑されている.

\section{2 標識 照明}

高速道路の標識は, 高所に大きな標識板が設置され, 夜間ヘッドラィトの下向き点灯では必要視認距離からの 判別が困難なため, 照明設備を設けるととが考慮されて いる.

道路の側方に設ける注意標識は，ヘッドライト拒よび 道路照明が有効に作用するので，特に照明は設けない．

アメリカでは EL 光源による標識照明の例もあるが, 都心で周团が比較的明るい時刻の場合は，現在のとてろ 輝度が不足して招り，かつ価格の点で難点がある.

\section{5. あとがき}

以上高速道路扔よびその照明の概要について述べたの であるが, 関連する事項として配線方式, 灯柱の形状, 設置方法等については検討中である.

建設面からみると，現在配管括よび灯柱の基礎を土木 構造物と共に施工し始めた段階であり, 灯具の設置は路 線の開通前になるであろう。それまでに灯具打よび灯柱 などの仕様を決定する必要があるが，灯具については新 しい器具の関発, 研究が進められて扰り, 灯柱について も照明器具工業会で照明用テーパーポールの規格を作成 されつつあるので期待されている.

照明学会に打いても道路照明委員会で各種の実験研究 報告が出されて怙り，一方高速道路調査会でも照明学会 関係者，道路関係 2 公団を含めて，照明分明金を設けて より広い視野に立った高速道路の照明基準の検討がなさ れつつある。

かくして，より良い照明基準が作成され，各方面のこ 協力により，首都にふさわしい道路照明ができるととを 念じつつ結びとしたい. 